\title{
False Unilateral Conductive Hearing Loss Due to Collapsed Ear Canals in a 78 Years Old Male
}

\author{
Mohammadsaleh Moosapour Bardsiri* \\ Department of Audiology, Iran
}

Submission: November 26, 2018; Published: December 04, 2018

*Corresponding author: Mohammadsaleh Moosapour Bardsiri, Department of Audiology, Iran

\begin{abstract}
Collapse of the external auditory meatus is common in elderly people. Sometimes, collapse of the external auditory meatus can cause misdiagnose during audiometry. So, inappropriate investigations and management may be undertaken. This report presents a case of ear canal collapse in an elderly and demonstrates the value of impedance audiometry in cases of collapse of the external ear canal and the way to overcome this phenomenon.
\end{abstract}

Keywords: Elderly; Ear Canal Collapse; Conductive Hearing Loss

\section{Introduction}

Some reports have suggested that the elderly population are more susceptible to ear canal collapse [1,2] mostly due to degenerative changes that take place in the ear canal. Air-bone gap typically is indicative of a conductive hearing loss. Healed tympanic membrane perforations, cerumen impact, partial ossicular chain disruption are some etiologies of the conductive hearing loss. One of the common etiologies of conductive hearing loss is ear canal collapse due to pressure of the earphone on the pinna during audiometry which usually has the greatest effect on frequencies above $1000 \mathrm{~Hz}$ [3]. There are some potential solutions for overcoming collapsible ear canals during audiometry including [2] using circumaural earphones with less pressure against the pinna; [1] using insert-type earphones; [3] manual positioning of earphone; [4] polyethene tubing inserts.

\section{Case Presentation}
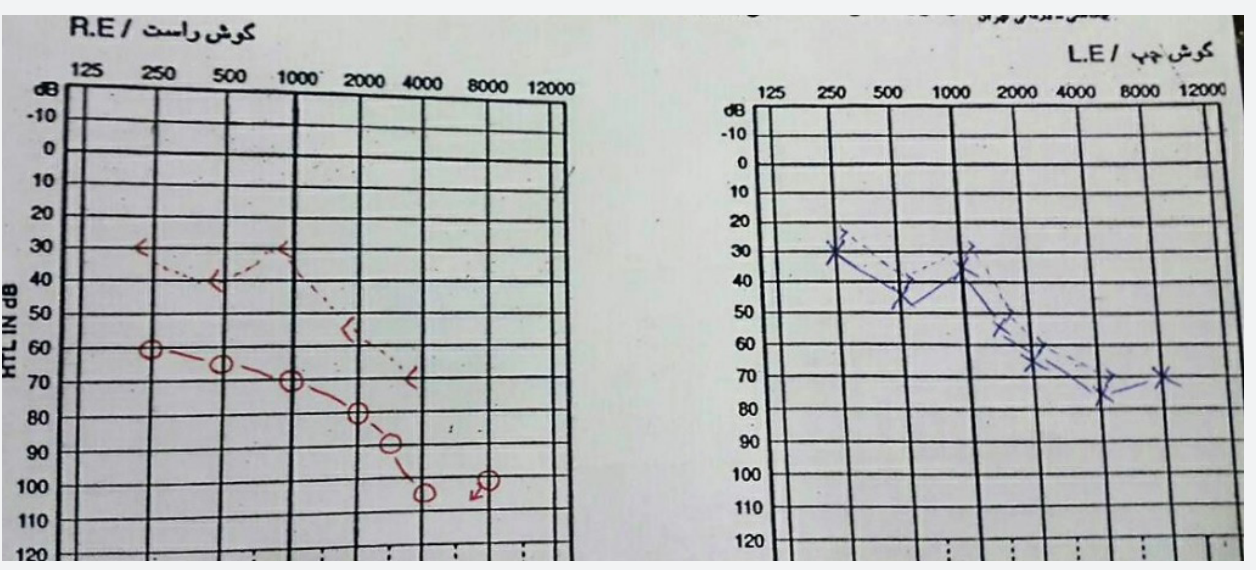

Figure 1: Before inserting polyethene tube.

A 78 years old male was referred to the audiology clinic of Tehran University of medical sciences with compliant of decreased hearing sensitivity in the last few months. Otoscopic examining reveled normal tympanic membrane bilaterally. Audiometric assessment was carried out in an acoustic booth (ANSI S12.2 standard) [2], using calibrated Inventis Harp Clinical audiometer (ANSI S3.6), using TDH-39 supra-aural headphones for air conduction and Radio ear B-71 bone oscillator for bone conduction testing. Audiometry revealed moderate conductive hearing loss in the right ear and moderate sensorineural hearing loss in the left ear (Figure 1). Tympanometry was carried out using a Zodiac 901 Tympanometer (ANSI S3.6) and the result was indicative of type (An) tympanogram bilaterally with present but elevated acoustic reflex thresholds. Because of an tympanogram and presence of acoustic reflex thresholds, collapsed ear canal was suspected and precise examination of the ear canal revealed 


\section{Global Journal of Otolaryngology}

collapsed ear canals which was overlooked before. Repeating pure tone audiometery with inserting a tympanometric probe tip inside the ear canal before placing headphone could solve the problem and bilateral moderate sensorineural hearing loss was obtained (Figure 2).

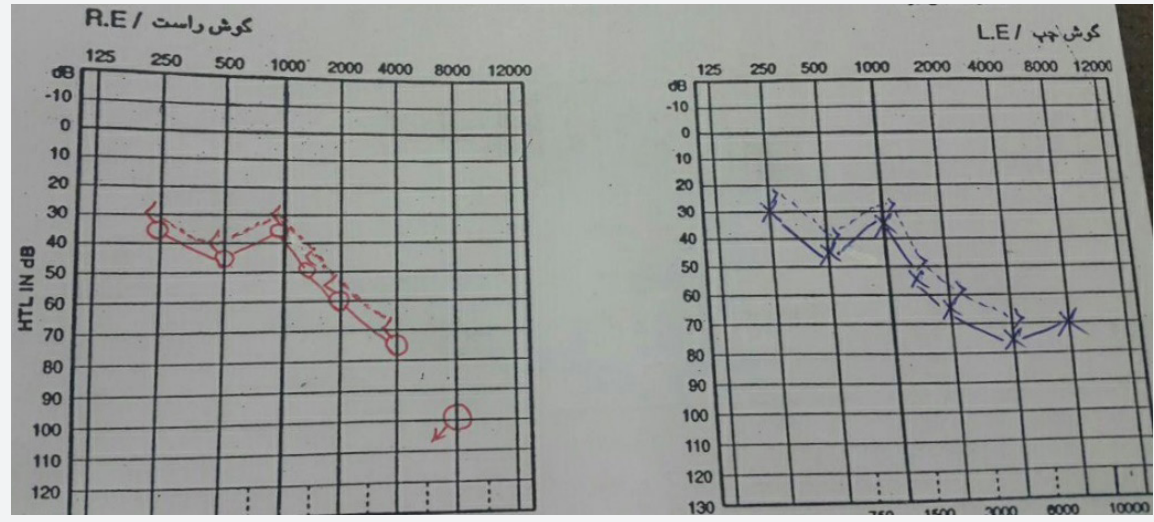

Figure 2: After inserting polyethene tube.

\section{Discussion}

Air bone gaps in this case has been observed unilaterally and across all frequency with larger air bone gaps at high frequencies. This finding is consistent with Marshal \& Grossman study who reported larger gaps at high frequencies in cases of collapsed ear canal [5]. Clinicians should pay more attention to detect any potential collapsed ear canals before starting audiometry. This is the case especially in elderly. Any conductive hearing loss especially at high frequencies, in spite of normal ear pressure and presence of acoustic reflex can be an indication. Using tympanometric ear tips, plastic tube or ear specula can be solutions to avoid this audiometric pitfall and may help clinicians prevent misdiagnosis by these simple procedures.

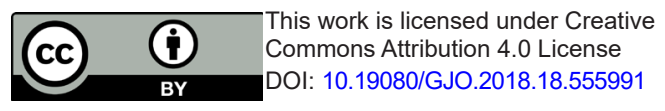

\section{References}

1. Bess JC (1971) Ear canal collapse: A review. Archives of Otolaryngology 93(4): 408-412.

2. (1970) Institute ANS. American National Standard specifications for audiometers: American National Standards Institute.

3. Carhart R, Jerger J (1959) Preferred method for clinical determination of pure-tone thresholds. Journal of Speech \& Hearing Disorders 24: 330-345.

4. Chaiklin JB, McClellan ME (1971) Audiometric management of collapsible ear canals. Archives of Otolaryngology 93(4): 397-407.

5. Marshall L, Gossman M (1982) A Management of ear-canal collapse. Archives of Otolaryngology 108(6): 357-361.

\section{Your next submission with Juniper Publishers will reach you the below assets}

- Quality Editorial service

- Swift Peer Review

- Reprints availability

- E-prints Service

- Manuscript Podcast for convenient understanding

- Global attainment for your research

- Manuscript accessibility in different formats

( Pdf, E-pub, Full Text, Audio)

- Unceasing customer service

Track the below URL for one-step submission https://juniperpublishers.com/online-submission.php 